\title{
PENGEMBANGAN MODUL PEMBELAJARAN FISIKA SMA TERINTEGRASI PENANGGULANGAN BENCANA TANAH LONGSOR
}

\author{
Widya Wati \\ Program Studi Pendidikan Fisika, FTK IAIN Raden Intan Lampung; e-mail: widya.fis57@gmail.com
}

\begin{abstract}
Abstrak: Wilayah Indonesia secara geologis dilalui oleh dua jalur pegunungan muda dunia yaitu Pegunungan Mediterania di sebelah barat dan Pegunungan Sirkum Pasifik di sebelah timur menyebabkan Indonesia banyak memiliki gunung api yang aktif dan rawan terjadi bencana. Oleh sebab itu diperlukan edukasi mitigasi bencana alam sejak dini. Edukasi mitigasi bencana alam dapat dilakukan dengan menintegrasikannya dalam pembelajaran. Penelitian ini bertujuan mengembangkan modul pembelajaran fisika yang terintegrasi penanggulangan bencana alam. Penelitian ini adalah penelitian pengembangan dengan menggunakan model 4D. Tahapan yang dilakukan adalah define, design, dan develop. Pada tahap define dilakukan analisis kurikulum, analisis konsep dan analisis mitigasi bencana alam. Pada tahap design dilakukan perancangan modul pembelajaran fisika. Tahap develop dilakukan pengembangan modul pembelajaran fisika SMA yang terintegrasi penanggulangan bencana alam tanah longsor. Hasil penelitian menghasilkan modul pembelajaran fisika yang dirancang untuk penanggulangan benaca alam tanah longsor.
\end{abstract}

Kata Kunci: modul pembelajaran fisika, penanggulangan bencana, tanah longsor

\section{PENDAHULUAN}

Wilayah Indonesia secara geologis dilalui oleh dua jalur pegunungan muda dunia yaitu Pegunungan Mediterania di sebelah barat dan Pegunungan Sirkum Pasifik di sebelah timur menyebabkan Indonesia banyak memiliki gunung api yang aktif dan rawan terjadi bencana. Bencana alam yang sering terjadi di wilayah Indonesia antara lain: banjir, kemarau panjang, tsunami, gempa bumi, gunung berapi dan tanah longsor.

Secara garis besar, Indonesia terdiri dari 2 musim yakni musim kemarau dan musim hujan. Musim kemarau terjadi dalam rentang bulan april sampai oktober, sedangkan musim hujan terjadi pada bulan oktober hingga april. Memasuki awal bulan oktober, Indonesia akan mulai memasuki musim penghujan. Bencana alam yang harus diantisipasi memasuki musim hujan adalah bencana tanah longsor. Diperlukan edukasi mitigasi terhadap bencana tanah longsor lebih awal agar dapat mengantisipasi korban-korban dari bencana tanah longsor.

Edukasi mitigasi bencana tanah longsor juga dapat dimulai dari sekolah dengan mengintegrasikan pembelajaran fisika dengan penanggulangan bencana tanah longsor. Pengintegrasian ini salah satunya dapat dilakukan dalam pembuatan bahan ajar. Salah satu bahan ajar yang dapat yang digunakan disekolah adalah modul pembelajaran.

Penintegrasian penanggulangan bencana tanah longsor pada modul pembelajaran fisika dilakukan dengan menganalisis kejadian tanah longsor dengan analisis fisika.

Adapun tujuan penelitan ini adalah untuk menghasilkan produl berupa model pembelajaran fisika SMA yang terintegrasi penanggulangan bencana tanah longsor.

\section{LANDASAN TEORI \\ Modul Pembelajaran Fisika}

Modul adalah salah satu jenis dari bahan ajar. Bahan ajar adalah substansi yang akan disampaikan dalam proses belajar mengajar (Djamarah, 2006). Tanpa bahan pelajaran proses belajar mengajar tidak akan berjalan. Karena itu, guru yang akan mengajar pasti memiliki dan menguasai bahan pelajaran yang akan disampaikannya pada anak didik. Bahan ajar merupakan salah satu sumber belajar 
siswa. Puskur (2007) menegaskan bahwa bahan ajar adalah seperangkat materi yang disusun secara sistematis baik tertulis maupun tidak sehingga tercipta lingkungan/suasana yang memungkinkan siswa untuk belajar.

\section{Tanah Longsor}

Tanah longsor adalah perpindahan material pembentuk lereng berupa batuan, bahan rombakan, tanah, atau material campuran tersebut, bergerak ke bawah atau keluar lereng. Secara umum kejadian longsor disebabkan oleh dua faktor yaitu faktor pendorong dan faktor pemicu. Faktor pendorong adalah faktor-faktor yang mempengaruhi kondisi material sendiri, sedangkan faktor pemicu adalah faktor yang menyebabkan bergeraknya material tersebut.

Tanah longsor terjadi pada permukaan bumi berupa lereng atau secara fisisnya berupa wilayah yang berbentuk bidang miring seperti gambar 1 berikut:

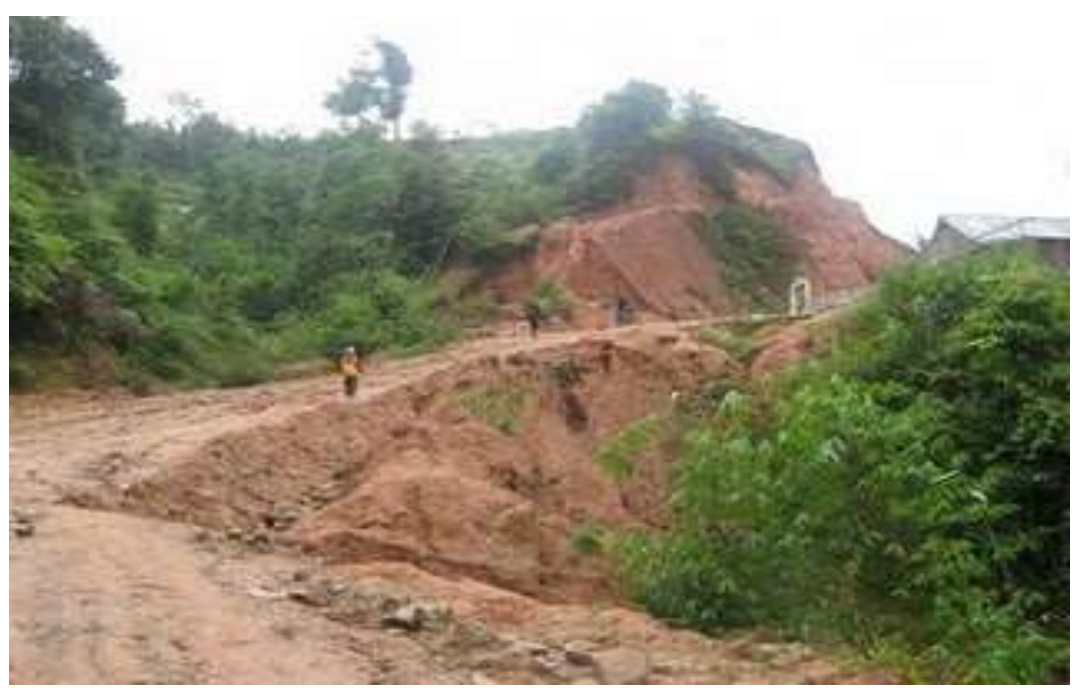

Gambar 1. Lereng gunung yang berbentuk miring

Proses terjadinya tanah longsor dapat diterangkan secara ringkas yaitu: air yang meresap ke dalam tanah akan menambah bobot tanah. Jika air tersebut menembus sampai tanah kedap air yang berperan sebagai bidang gelincir, maka tanah menjadi licin dan tanah pelapukan di atasnya akan bergerak mengikuti lereng dan keluar lereng.

Dari proses singkat di atas, maka longsor dapat terjadi jika kestabilan lereng terganggu. Berikut ini akan dijelaskan faktor-faktor yang mengganggu kestabilan lereng tersebut.

\section{Gaya gravitasi}

Pada lereng berupa bidang miring, gaya gravitasi / gaya berat dapat diuraikan menjadi komponen gaya gravitasi pada arah sumbu y $\left(w_{y}\right)$ dan arah sumbu $\mathrm{x}\left(w_{x}\right)$ seperti pada gambar 2.

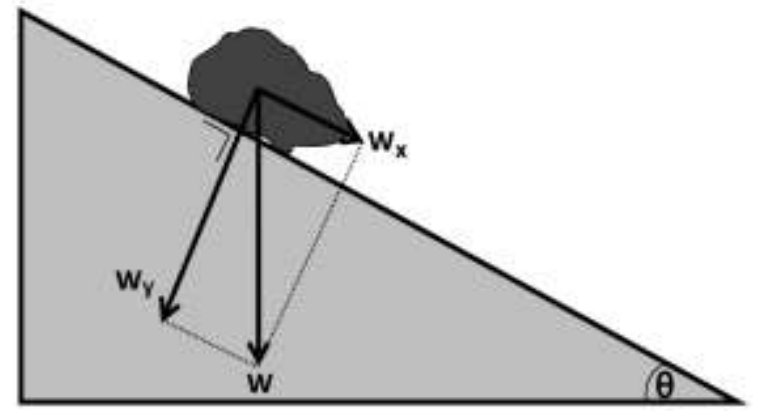

Gambar 2. Sebaran gaya pada bidang miring 
Pada gambar 2, $w_{y}$ menahan material agar tetap berada pada posisinya di atas permukaan lereng disebut dengan gaya pendicular, sedangkan $w_{x}$ menyebabkan material terlepas dan tertarik sehingga bergerak turun sejajar lereng disebut dengan tegangan pelepas.

Jika lereng makin curam artinya sudut kemiringan lereng bertambah $(\theta>>)$, maka $w_{x}$ juga makin besar sedangkan $w_{y}$ berkurang, dengan persamaan :

$$
\left.\begin{array}{l}
\mathrm{w}_{\mathrm{x}}=\mathrm{w} \cdot \sin \theta \\
\mathrm{w}_{\mathrm{y}}=\mathrm{w} \cdot \cos \theta
\end{array}\right\} \theta>>, \sin \theta>>\text { dan } \cos \theta<<
$$

Jika $w_{x}>w_{y}$, maka material akan bergerak menuruni lereng

Jika $w_{x}>$ gaya kohesi antara material penyusun permukaan lereng (sep : tanah, tanah liat, pasir, dll), maka material tersebut akan bergerak menuruni lereng

\section{Peranan air}

Meskipun air tidak selalu terlibat langsung sebagai medium pengantar pada proses longsor, air memegang peranan penting. Penambahan air akibat hujan atau lelehan salju menyebabkan penambahan berat material lereng. Air meresap ke dalam tanah atau batuan sehingga menggantikan udara yang mengisi pori-pori antar partikel atau rongga patahan. Jika air lebih berat dari udara, maka terjadi penambahan berat material. Karena berat adalah gaya gravitasi, maka air akan menambah tegangan pelepas material sehingga material pun akan bergerak menuruni lereng dengan mudahnya.

a. Air memiliki kemampuan mengubah sudut repose (sudut kestabilan lereng). Sudut repose ini merupakan sudut tercuram dari onggokan butiran sejumlah material yang tidak stabil dan dikontrol oleh hubungan pergeseran antara butiran seperti gambar 3. Secara umum, sudut repose untuk material kering akan bertambah jika terjadi penambahan ukuran butiran, tetapi biasanya berkisar antara $30^{\circ}$ dan $37^{\circ}$.

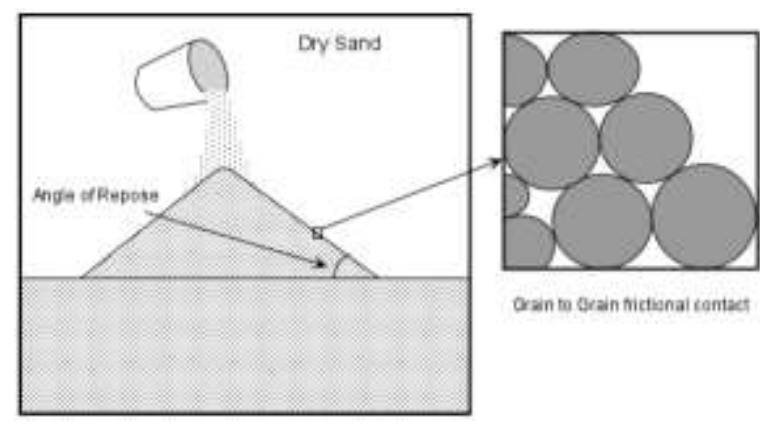

Gambar 3. Butir pasar yang kering

Sebagian material basah mengakibatkan sudut repose yang sangat besar karena air menyebabkan gaya kohesi antara butiran tanah meningkat sehingga butiran tetap pada posisinya.

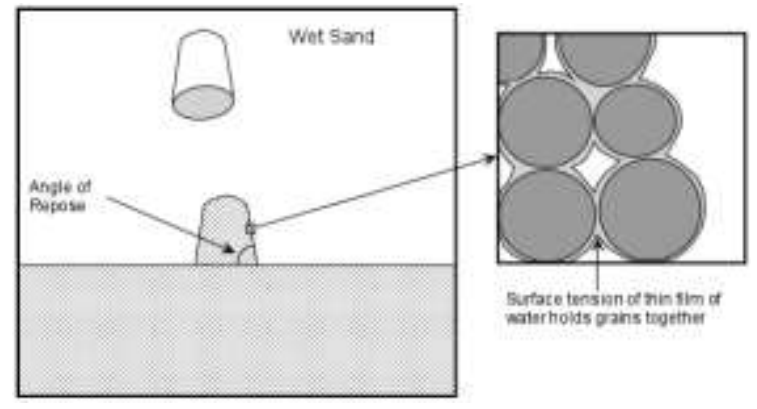

Gambar 4. Gaya kohesi butiran tanah

Saat material dipenuhi oleh air, sudut repose semakin berkurang menuju nilai yang sangat kecil dan material cenderung mengalir seperti cairan. Hal ini terjadi karena adanya lapisan air antara butiranbutiran dan memisahkan butiran tersebut dari ikatan antara butirannya. 


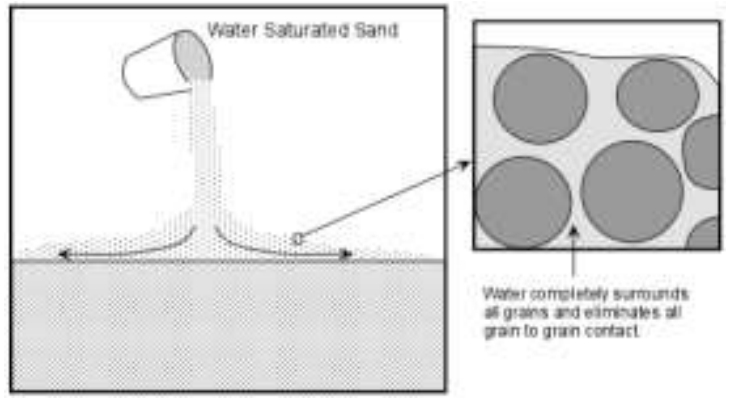

Gambar 5. Aliran air yang memisahkan butir tanah

a. Air mampu melepaskan mineral pada tanah. Jika penyerapan terjadi, maka ikatan sentuh pada permukaan antara butiran mineral menjadi hilang sehingga menyebabkan butiran kehilangan gaya kohesi, dengan demikian tanah akan kehilangan ketahanannya.

b. Air mempunyai kemampuan untuk melarutkan mineral-mineral perekat yang mengikat seluruh butiran material. Air yang meresap ke dalam tanah akan merembeskan perekat butiran tersebut sehingga juga akan mengurangi gaya kohesi antara butiran tanah.

c. Kuantitas air dapat menyebabkan pergantian massa padat menjadi massa cair pada onggokan tanah sehingga butiran-butiran tanah akan merembes dengan sendirinya.

\section{Material pengganggu}

Seperti air yang menyerap dan mengisi pori-pori butiran tanah, air dan material pengganggu secara bersamaan bisa merembes ke dalam mineral-mineral tanah lempung.

\section{Struktur dan material yang lemah}

Jika terdapat batuan atau tanah lemah di antara batuan atau tanah lemah

a. Jalan raya di pegunungan

b. Lapisan yang lemah

\section{Peristiwa pemicu}

a. Peristiwa tiba-tiba

Misalnya: gempa bumi, pohon tertiup angin, guncangan truk di jalan, ledakan yang dibuat manusia

b. Modifikasi lereng

Modifikasi lerenag baik yang disebabkan oleh manusia atau oleh alam dapat menyebabkan perubahan pada sudut kemiringan lereng

c. Pengikisian air pada tebing

d. Perubahan karakteristik hidrologi

Perubahan kareteristik hidrologi akibat hujan dapat menjenuhkan batu dan meningkatkan berat. Perubahan dalam sistem air tanah dapat meningkatkan atau menurunkan tekanan fluida di batuan sehingga memicu terjadinya longsor.

\section{Pencegahan Terjadinya Bencana Tanah Longsor}

Cara mencegahan bencana tanah longsor daat dilihat pada gambar dan penjelasannya berikut.
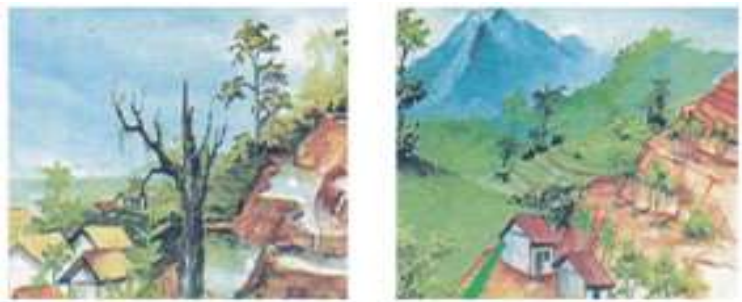

Gambar 6. Sawah di lereng gunung

Jangan mencetak sawah dan membuat kolam pada lereng bagian atas di dekat pemukiman (gb. Kiri) Buatlah terasering (sengkedan) [ada lereng yang terjal bila membangun permukiman (gb. kanan) 

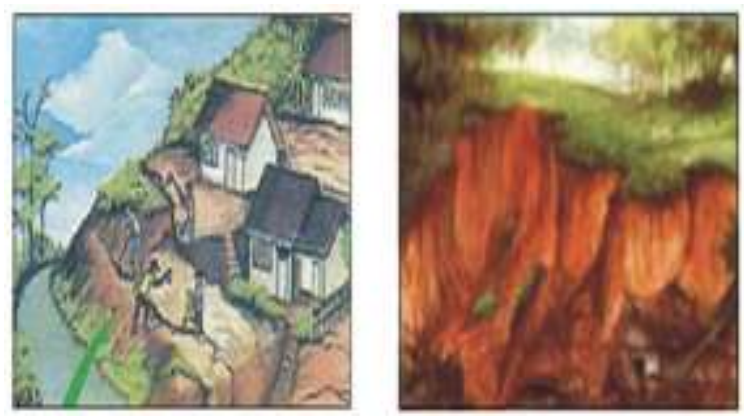

Gambar 7. Rumah di lereng gunung

Segera menutup retakan tanah dan dipadatkan agar air tidak masuk ke dalam tanah melalui retakan. (gb. kiri) Jangan melakukan penggalian di bawah lereng terjal. (gb. kanan)
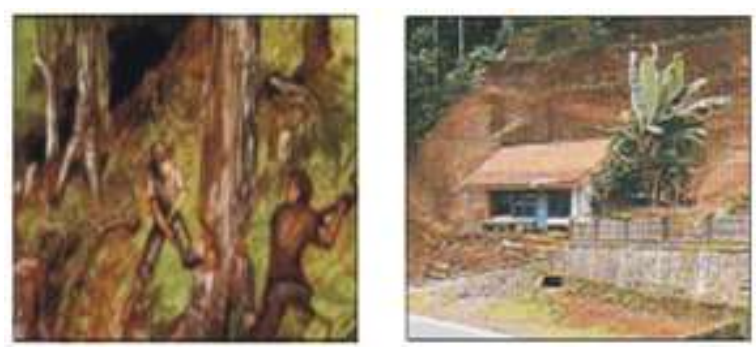

Gambar 8. Penebangan pohon di lereng gunung

Jangan menebang pohon di lereng (gb. kiri) Jangan membangun rumah di bawah tebing. (gb. kanan)
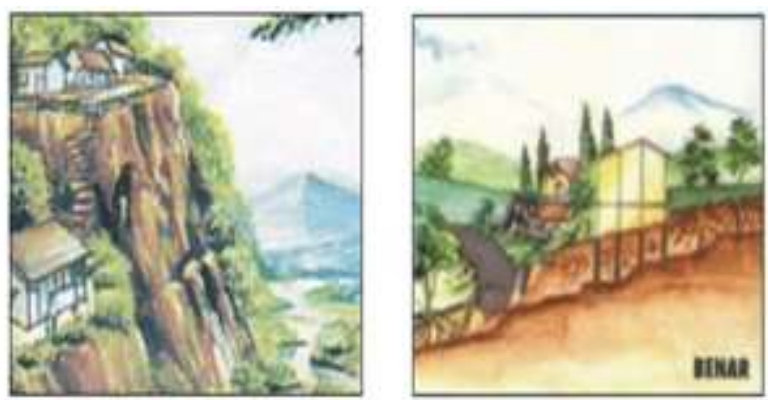

Gambar 9. Pembangunan rumah di lereng gunung
Jangan mendirikan permukiman di tepi lereng yang terjal (gb.kiri) Pembangunan rumah yang benar di lereng bukit. (gb.kanan)
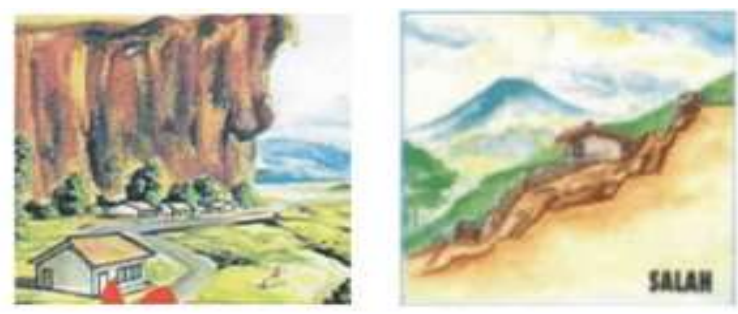

Gambar 10. Pendirian rumah di bawah tebing

Jangan mendirikan bangunan di bawah tebing yang terjal. (gb.kiri) Pembangunan rumah yang salah di lereng bukit. (gb.kanan)
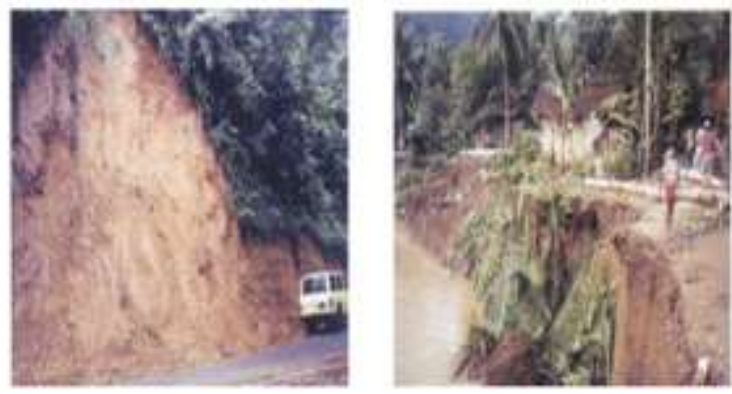

Gambar 11. Jalan di lereng Gunung

Jangan memotong tebing jalan menjadi tegak. (gb.kiri) Jangan mendirikan rumah di tepi sungai yang rawan erosi. (gb.kanan).

\section{Tahapan Mitigasi Bencana Tanah Longsor}

1. Pemetaan

Menyajikan informasi visual tentang tingkat kerawanan bencana alam geologi di suatu wilayah, sebagai masukan kepada masyarakat dan atau pemerintah kabupaten/kota dan provinsi sebagai data dasar untuk melakukan pembangunan wilayah agar terhindar dari bencana. 
2. Pemeriksaan

Melakukan penyelidikan pada saat dan setelah terjadi bencana, sehingga dapat diketahui penyebab dan cara penaggulangannya.

\section{Pemantauan}

Pemantauan dilakukan di daerah rawan bencana, pada daerah strategis secara ekonomi dan jasa, agar diketahui secara dini tingkat bahaya, oleh pengguna dan masyarakat yang bertempat tinggal di daerah tersebut.

\section{Sosialisasi}

Memberikan pemahaman kepada Pemerintah Provinsi /Kabupaten /Kota atau Masyarakat umum, tentang bencana alam tanah longsor dan akibat yang ditimbulkannnya. Sosialisasi dilakukan dengan berbagai cara antara lain, mengirimkan poster, booklet, dan leaflet atau dapat juga secara langsung kepada masyarakat dan aparat pemerintah

\section{Pemeriksaan bencana longsor}

Bertujuan mempelajari penyebab, proses terjadinya, kondisi bencana dan tata cara penanggulangan bencana di suatu daerah yang terlanda bencana tanah longsor.

\section{Penanggulangan Bencana Tanah Longsor}

Usaha mitigasi bencana tanah longsor berarti segala usaha untuk meminimalkan akibat terjadinya tanah longsor. Langkahlangkah yang dilakukan untuk menekan bahaya tanah longsor dibagi menjadi tiga, yaitu:

\section{Tahap awal atau tahap preventif}

Tahap awal dalam upaya meminimalkan kerugian akibat bencana tanah longsor adalah sebagai berikut.

a) Mengidentifikasi daerah rawan dan melakukan pemetaan. b) Penyuluhan pencegahan dan penanggulangan bencana alam dengan memberikan informasi mengenai bagaimana dan mengapa tanah longsor.

c) Pemantauan daerah rawan longsor.

d) Perencanaan pengembangan sistem peringatan dini di daerah rawan bencana.

e) Menghindari bermukim atau mendirikan bangunan di tepi lembah sungai terjal.

f) Menghindari melakukan penggalian pada daerah bawah lereng terjal yang akan mengganggu kestabilan lereng sehingga mudah longsor.

g) Menghindari membuat sawah baru dan kolam pada lereng yang terjang karena air yang digunakan akan memengaruhi sifat fisik lereng. Lereng menjadi lembek dan gembur sehingga tanah mudah bergerak.

h) Menyebarluaskan informasi bencana gerakan tanah melalui berbagai media sehingga masyarakat mengetahui.

2. Tahap bencana

Usaha yang perlu dilakukan ketika suatu daerah terkena bencana tanah longsor antara lain berikut ini.

a) Menyelamatkan warga yang tertimpa musibah.

b) Pembentukan pusat pengendalian atau crisis center.

c) Evakuasi korban ke tempat yang lebih aman.

d) Pendirian dapur umum, pos-pos kesehatan, dan penyediaan air bersih.

e) Pencegahan berjangkitnya wabah penyakit.

f) Evaluasi, konsultasi, dan penyuluhan.

3. Tahap pascabencana

Setelah bencana tanah longsor terjadi, bukan berarti permasalahan selesai, tetapi masih ada tahapan yang perlu dilakukan untuk mengurangi jumlah kerugian, yaitu: 
a) Mengupayakan mengembalikan fungsi hutan lindung seperti sediakala.

b) Mengevaluasi dan memperketat studi Amdal pada kawasan vital yang berpotensi menyebabkan bencana.

c) Penyediaan lahan relokasi penduduk yang bermukim di daerah bencana, dan di sepanjang bantaran sungai.

d) Normalisasi area penyebab bencana.

e) Rehabilitasi sarana dan prasarana pendukung kehidupan masyarakat yang terkena bencana alam secara permanen.

f) Menyelenggarakan forum kerja sama antardaerah dalam penanggulangan bencana.

\section{Integrasi Bencana Tanah Longsor pada Materi Fisika}

Bencana tanah longsor dapat diintegrasikan pada pembelajaran fisika pada bahasan hukum Newton. Material tanah longsor yang berada pada lereng gunung dapat dianalisis dengan hukum newton pada bidang miring.

Pada lereng berupa bidang miring, gaya gravitasi / gaya berat dapat diuraikan menjadi komponen gaya gravitasi pada arah sumbu y $\left(w_{y}\right)$ dan arah sumbu $\mathrm{x}\left(w_{x}\right)$ seperti pada gambar 11 .

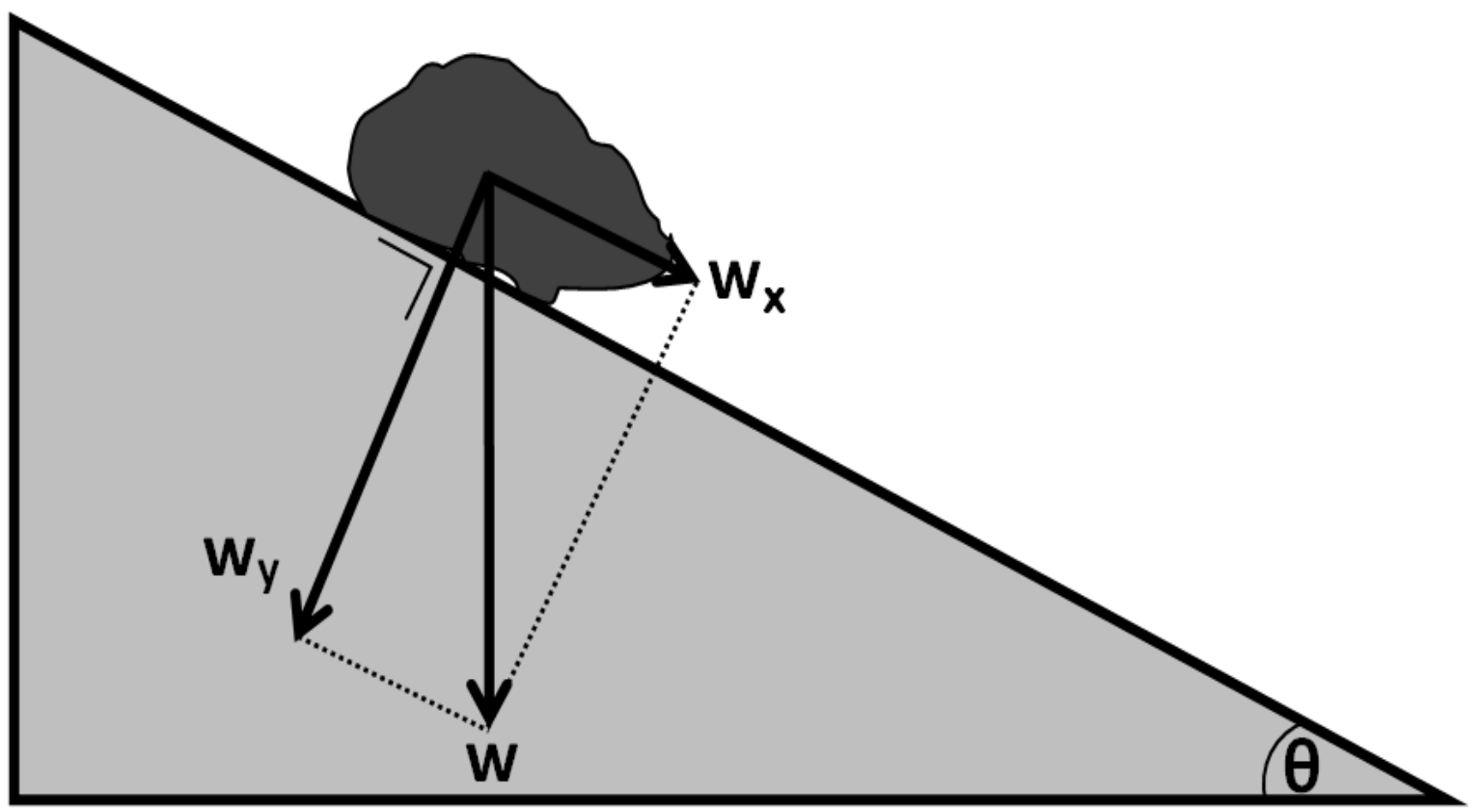

Gambar 12. Analisis gaya pada bidang miring

Pada gambar 11, $w_{y}$ menahan material agar tetap berada pada posisinya di atas permukaan lereng disebut dengan gaya pendicular, sedangkan $w_{x}$ menyebabkan material terlepas dan tertarik sehingga bergerak turun sejajar lereng disebut dengan tegangan pelepas.

Jika lereng makin curam artinya sudut kemiringan lereng bertambah $(\theta>>)$, maka $w_{x}$ juga makin besar sedangkan $w_{y}$ berkurang, dengan persamaan :

$$
\left.\begin{array}{l}
\mathrm{w}_{\mathrm{x}}=\mathrm{w} \cdot \sin \theta \\
\mathrm{w}_{\mathrm{y}}=\mathrm{w} \cdot \cos \theta
\end{array}\right\} \begin{aligned}
& \theta>>, \sin \theta>>\text { dan } \\
& \cos \theta<<
\end{aligned}
$$

Jika $w_{x}>w_{y}$, maka material akan bergerak menuruni lereng

Jika $w_{x}>$ gaya kohesi antara material penyusun permukaan lereng (sep : tanah, tanah liat, pasir, dll), maka material tersebut akan bergerak menuruni lereng 


\section{METODE PENELITIAN}

Kegiatan yang dilakukan pada penelitian ini adalah mengembangkan modul pembelajaran yang terintegrasi penanggulangan bencana tanah longsor.

Berdasarkan kegiatan penelitian yang dilakukan, jenis penelitian ini adalah penelitian pengembangan. Hal ini sesuai dengan yang dikemukakan oleh Emzir (2007) bahwa penelitian pengembangan adalah penelitian yang bertujuan untuk menghasilkan produk baru. Lebih lanjut Emzir (2007) menyatakan bahwa dalam bidang pendidikan tujuan utama penelitian dan pengembangan bukan untuk merumuskan atau menguji teori, tetapi untuk mengembangkan produk-produk yang efektif untuk digunakan di sekolahsekolah. Produk-produk dikembangkan untuk mengetahui kebutuhan-kebutuhan tertentu dengan spesifikasi yang detail. Dalam hal ini peneliti akan mengembangakan suatu modul pembelajaran fisika terintegrasi penanggulangan bencana tanah longsor.

Modul pembelajaran ini dikembangkan dengan model 4-D (four-D models), yang terdiri dari empat tahap. Menurut Thiagajaran (1974), keempat tahap itu adalah pendifinisian (define), perancangan (design), pengembangan (develop) dan penyebaran (disseminate). Mengingat keterbatasan waktu dan biaya, penelitian ini dilakukan sampai tahap develop atau pengembagan saja. Langkah-langkah pengembangan perangkat pembelajaran ini dapat dilihat pada gambar 12.

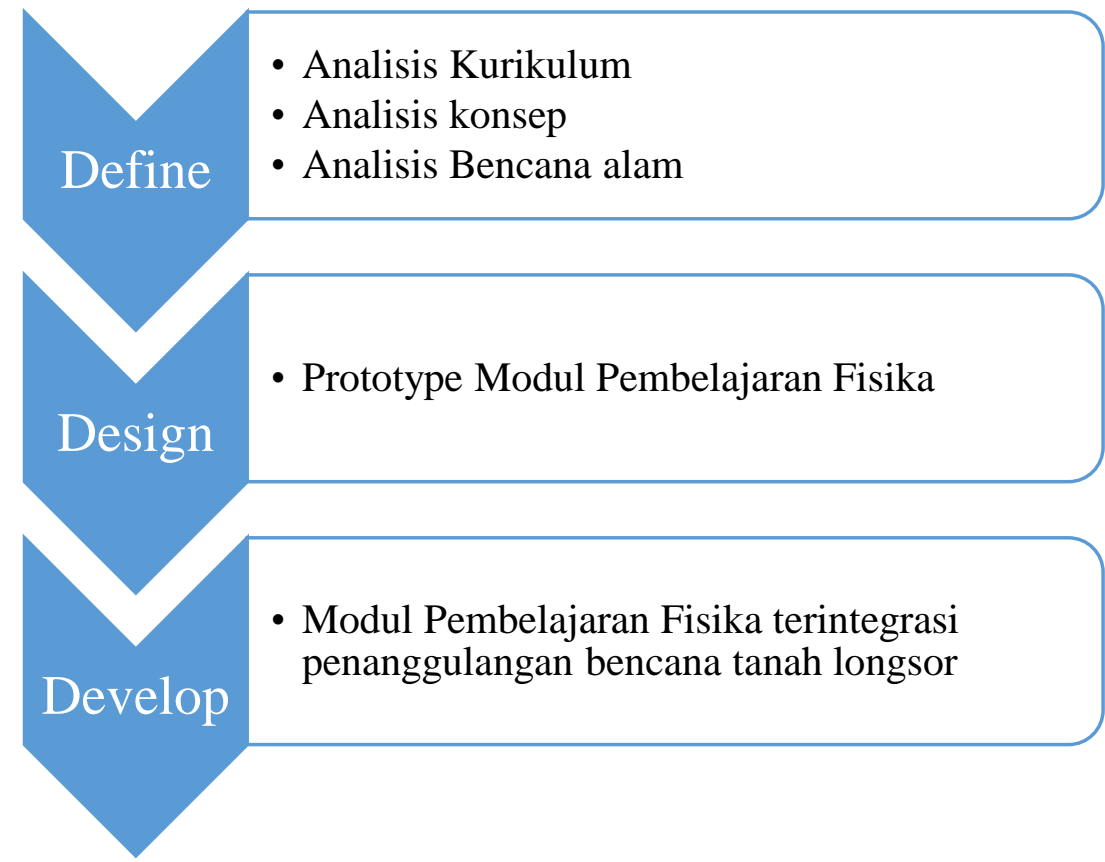

Gambar 13. Langkah-langkah 3-D Models Pengembangan Perangkat Pembelajaran (Dimodifikasi dari Thiagarajan, 1974) 


\section{Tahap Pendifinisian}

Pelaksanaan penelitian dimulai dengan tahap define. Pada tahap define ini dilakukan penetapan syarat-syarat pembelajaran dengan menganalisis standar kompetensi dan batasan materi pembelajaran yang akan diajarkan oleh guru berdasarkan isi kurikulum. Pada tahap ini dilakukan kurikulum, analisis konsep dan analisis mitigasi bencana alam. Hasil analisis kurikulum, analisis konsep, analisis mitigasi bencana alam dideskripsikan berikut ini.

\section{a. Analisis Kurikulum}

Berdasarkan panduan KTSP, materi hukum newton dibahas pada konsep gerak dengan standar kompetensi menerapkan konsep dan prinsip dasar kinematika dan dinamika benda titik. Kompetensi dasar pada materi gerak ini adalah 1) Menganalisis besaran fisika pada gerak dengan kecepatan dan percepatan konstan 2) Menganalisis besaran fisika pada gerak melingkar dengan laju konstan 3) Menerapkan Hukum Newton sebagai prinsip dasar dinamika untuk gerak lurus, gerak vertikal, dan gerak melingkar beraturan

\section{b. Analisis Konsep}

Pada langkah ini dilakukan kegiatan yaitu mengidentifikasi, merinci dan menyusun secara sistematis materi-materi utama yang akan dipelajari oleh siswa, selanjutnya materi tesebut disusun secara hirarkis.

\section{c. Analisis Mitigasi Bencana Alam}

Pada langkah ini dilakukan kegiatan mengidentifikasi langkah-langkah mitigasi bencana tanah longsor.

\section{Tahap Perencanaan}

Tahap ini bertujuan untuk merancang modul pembelajaran fisika. Modul pembelajaran fisika dirancang secara sistematis memuat kriteria-kriteri modul pembelajaran yang baik.

\section{Tahap Pengembangan}

Tujuan tahap ini adalah untuk menghasilkan modul pembelajaran fisika yang terintegrasi penanggulangan bencana tanah longsor.

\section{HASIL DAN PEMBAHASAN}

Setelah melakukan serangkaian langkah penelitian mengenai pengembangan modul pembelajaran fisika terintegrasi penanggulangan bencana tanah longsor maka dapat dideskripsikan hasil penelitian sebagai berikut.

\section{Hasil Tahap Pendefinisian}

Hasil Tahap Analisis Kurikulum

Dalam KTSP tidak semua komponen kurikulum dikembangkan oleh sekolah. Standar kompetensi lulusan, standar kompetensi, kompetensi dasar, kerangka dasar dan struktur kurikulum disusun secara terpusat oleh Badan Standar Nasional Pendidikan (BNSP).

Dalam kurikulum yang dibuat oleh BNSP, standar kompetensi untuk kelas XI semester pertama, Mendeskripsikan gejala alam dalam cakupan mekanika klasik sistem diskret (partikel). Kompetensi dasarnya adalah Menginterpretasikan hukum-hukum Newton dan penerapannya pada gerak benda

Berdasarkan standar kompetensi dan kompetensi dasar yang sudah dibuat oleh BSNP ini dikembangkan bahan ajar berupa modul pembelajaran fisika. Dalam penelitian ini modul yang dikembangkan adalah modul pembelajaran fisika terintegrasi penanggulangan bencana tanah longsor.

\section{Hasil Tahap Analisis Konsep}

Sebagaimana telah dijabarkan pada analisis kurikulum bahwa untuk standar kompetensi standar kompetensi untuk kelas XI semester pertama, Mendeskripsikan gejala alam dalam cakupan mekanika klasik 
sistem diskret (partikel). Kompetensi dasarnya adalah Menginterpretasikan hukum-hukum Newton dan penerapannya pada gerak benda. Untuk itu analisis konsep untuk penelitian ini adalah gerak dalam mekanika dilihat pada Gambar 14.

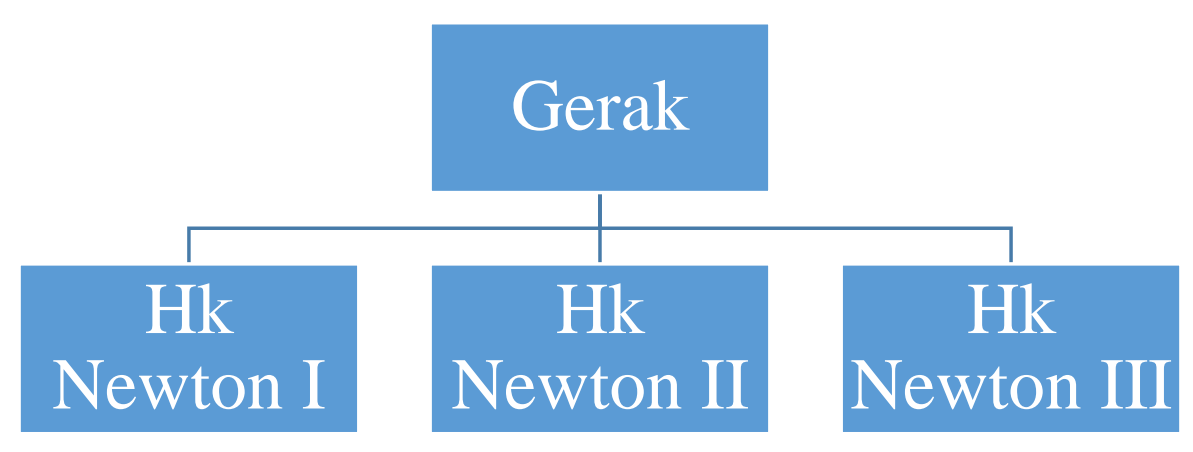

Gambar 14. Peta Konsep gerak dalam mekanika

Berdasarkan analisis konsep, maka diperoleh gambaran umum tentang gerak dengan hukum newton I, II, III

\section{Hasil Tahap Analisis Penanggulangan Bencana Tanah Longsor}

Tanah longsor adalah perpindahan material pembentuk lereng berupa batuan, bahan rombakan, tanah, atau material campuran tersebut, bergerak ke bawah atau keluar lereng. Secara umum kejadian longsor disebabkan oleh dua faktor yaitu faktor pendorong dan faktor pemicu. Faktor pendorong adalah faktor-faktor yang mempengaruhi kondisi material sendiri, sedangkan faktor pemicu adalah faktor yang menyebabkan bergeraknya material tersebut.

\section{Hasil Tahap Perancangan}

Setelah melihat analisa dari tahap pendefenisian, penelitian dilanjutkan ke tahap peancangan. Pada tahap perancangan ini dilakukan untuk merancang modul pembelajaran. Adapun modul pembelajaran yang dirancang adalah modul pembelajaran fisika terintegrasi penanggulangan bencana tanah longsor.

\section{Hasil tahap Pengembangan}

Setelah menyelesaikan tahap perancangan yang menghasilkan prototype modul pembelajaran, maka langkah selanjutnya adalah memulai tahap pengembangan. Tahap pengembangan ini diawali dengan merapikan prototype modul pembelajaran fisika dan mengintegrasikan modul pembelajaran fisika dengan penanggulangan bencana tanah longsor

\section{SIMPULAN}

Berdasarkan hasil penelitian diperoleh modul pembelajaran fisika terintegrasi penanggulangan bencana tanah longsor

\section{DAFTAR PUSTAKA}

Dhamarah, Bahri Syaiful dan Zain, Aswan. 2006. Strategi Belajar Mengajar. Jakarta: Rineka Cipta

Emzir,2011. Metodologi Penelitian Pendidikan Kuantitatif dan Kualitatif. Jakarta: Raja Grafindo Persada 
Nelson, Stephen. 2009. Natural Disaster :

Slope Stability, Triggering Events,

Mass Wasting Events. Tulane

University :

(http://www.tulane.edu/ sanelson/geo

1204/slopestability.htm.)

Pusat Kurikulum (Puskur). 2007.

Sosialisasi Materi Dan Pelatihan

Kurikulum Tingkat Satuan Pendidikan

(KTSP). Jakarta: Depdiknas 